\title{
USE OF MODIFIED STARCH AND MILK PROTEIN ISOLATE IN THE TECHNOLOGY OF HARD DOUGH COOKIES FOR SPECIAL PURPOSE
}

\author{
A. Dorohovych, M. Petrenko \\ National University of Food Technologies
}

\begin{tabular}{|c|c|}
\hline Key words: & ABSTRACT \\
\hline $\begin{array}{l}\text { Functional foods } \\
\text { Protracted cookies } \\
\text { Nutritiology } \\
\text { Crosslinked starch } \\
\text { Protein isolate }\end{array}$ & $\begin{array}{l}\text { The article describes the results of theoretical and } \\
\text { experimental studies on the use of the technology of hard } \\
\text { dough cookies made of modified starch and milk protein } \\
\text { isolate. Hard dough cookies were selected as an object of } \\
\text { study, as they have a balanced chemical composition of }\end{array}$ \\
\hline $\begin{array}{l}\quad \text { Article history: } \\
\text { Received } 17.05 .2017 \\
\text { Received in revised form } \\
\text { 03.06.2017 } \\
\text { Accepted } 18.06 .2017\end{array}$ & $\begin{array}{l}\text { proteins, fats and carbohydrates. Attention is paid to the } \\
\text { choice of the optimal ratio of new raw materials, their } \\
\text { impact on the quality of the finished product and semi- } \\
\text { finished products used in its production (emulsion and } \\
\text { dough). The impact of modified starch and milk protein }\end{array}$ \\
\hline $\begin{array}{l}\text { Corresponding author: } \\
\text { A. Dorohovych } \\
\text { E-mail: } \\
\text { npnuht@ukr.net }\end{array}$ & $\begin{array}{l}\text { isolate on baking processes and preservation of protracted } \\
\text { cookies has been described. The significant influence of new } \\
\text { raw materials on the structural and mechanical properties of } \\
\text { the dough is proved, as it acquires more elastic properties } \\
\text { due to the increase in the amount of bound moisture. It is } \\
\text { established that the introduction of starch and protein isolate } \\
\text { prolongs the duration of heat treatment of a hard dough } \\
\text { cookie. Hard dough cookies with new raw materials have } \\
\text { good organoleptic characteristics, as well as high biological } \\
\text { and nutritional value. They are enriched with proteins and } \\
\text { dietary fibers and have the status of a functional product, } \\
\text { since they provide } 20 \% \text { of the daily human need for fiber. }\end{array}$ \\
\hline
\end{tabular}

DOI: $10.24263 / 2225-2924-2017-23-4-21$

\section{ВИКОРИСТАННЯ МОДИФІКОВАНОГО КРОХМАЛЮ ТА ІЗОЛЯТУ МОЛОЧНОГО БІЛКА В ТЕХНОЛОГІї ЗАТЯЖНОГО ПЕЧИВА СПЕЦІАЛЬНОГО ПРИЗНАЧЕННЯ}

\section{А.М. Дорохович, М.М. Петренко}

Національний університет харчових технологій

У статті описані результати теоретичних $i$ експериментальних досліджень щзодо використання у технології затяжного печива зиитого крохмалю та ізоляту молочного білка. Об'єктом для збагачення виступає затяжне печиво, оскільки воно має оптимальне співвідночення білків, жирів $і$ вугле- 
водів, порівняно з рештою видів печива. Увага приділена вибору оптимального співвідношення нових сировинних компонентів, їх впливу на якість затяжного печива та напівфабрикатів для його виробниитва (емульсія, тісто). Також охарактеризовано вплив зиитого крохмалю та білкового ізоляту на процеси термообробки та зберігання затяжного печива. Доведено суттєвий вплив нової сировини на структурно-механічні показники тіста, яке набуває більш пружних властивостей за рахунок збільшення кількості зв'язаної вологи. Встановлено, щзо внесення крохмалю і білкового ізоляту подовжує тривалість термообробки затяжного печива. Затяжне печиво з новою сировиною має хороші органолептичні показники, високу біологічну та харчову иінність, збагачене білками і харчовими волокнами, та має статус функиіонального продукту, оскільки забезпечує $20 \%$ добової потреби людини в клітковині.

Ключові слова: функціональні продукти, затяжне печиво, нутриціологія, зиитий крохмаль, білковий ізолят.

Постановка проблеми. Одним 3 актуальних напрямків розвитку кондитерської промисловості є розробка нових виробів функціонального призначення, які здатні забезпечувати необхідну кількість біологічно активних речовин у добовому раціоні сучасної людини. При зростаючих тенденціях до зниження калорійності харчових продуктів, потреба в макро- і мікронутрієнтах залишається незмінною, адже їх призводить до зниження імунітету, погіршення здоров'я і знижує якість життя.

Корисними вважаються продукти дієтичного та функціонального призначення, 3 високим вмістом біологічно активних компонентів (антиоксидантів, вітамінів, амінокислот, мінеральних речовин, харчових волокон), зі зниженою калорійністю, а також з низьким вмістом цукру і жиру. Вживання таких продуктів покращує фізіологічні процеси в організмі, зміцнює імунітет i загальний стан організму людини, а також сприяє профілактиці хронічних захворювань [1].

Перспективним шляхом створення продуктів дієтично-функціонального призначення $\epsilon$ збагачення існуючих продуктів біологічно активними речовинами за рахунок використання нетрадиційних видів сировини [2]. Серед борошняних кондитерських виробів хорошим об'єктом для збагачення $є$ затяжне печиво, оскільки серед всіх видів печива воно має найбільш збалансований хімічний склад за вмістом білків, жирів і вуглеводів, що робить його прийнятною основою для розробки продуктів здорового харчування.

Науковими дослідженнями, що стосуються питання розробки борошняних кондитерських виробів спеціального призначення займались такі відомі вчені, як: Туманов А.С., Дорохович А.М., Яременко О.М., Левачов М.О., Сверюков Г.Ф. та інші. Зокрема широкий комплекс досліджень щодо створення затяжного печива зі зниженою калорійністю та цукроємкістю був проведений Яременко О.М., в роботах якої [3; 4] доводиться доцільність використання в рецептурах затяжного печива дієтичних харчових волокон та цукрозамін- 
ників для надання йому дієтично-функціональних властивостей, а також проводиться глибокий аналіз впливу нової сировини на процеси приготування, термооброблення та зберігання печива.

Для поліпшення хімічного складу печива було прийнято рішення збагатити його клітковиною та білковими компонентами, оскільки ці компоненти $є$ одними 3 найбільш дефіцитних в сучасному раціоні. В якості джерела харчових волокон був використаний зшитий модифікований крохмаль, вміст клітковини в якому складає $60 \%$, а у якості джерела функціонального білка був обраний ізолят молочного білка. Використання даних видів функціональних компонентів дозволяе покращити хімічний склад затяжного печива, не вносячи при цьому суттєвих змін до технологічного процесу, о дозволить виготовляти дане печиво на існуючому обладнанні [5].

Мета статті: дослідити вплив зшитого модифікованого крохмалю та ізоляту молочного білка на якість затяжного печива структурно-механічні показники тіста та емульсії для його виробництва, а також на процеси термообробки i зберігання печива.

Матеріали і методи. Об'єктом досліджень було затяжне печиво, напівфабрикати (тісто, емульсія) і сировина для його приготування. В якості основної сировини використовувалося пшеничне борошно вищого гатунку, зшитий модифікований крохмаль марки «Ні-Маize», ізолят молочного білка, а також інші компоненти згідно рецептури на затяжне печиво. Для контролю вологості печива, напівфабрикатів і сировини використовували сушильну шафу СЕШ-3 і прилад Чижової. Для визначення пружності клейковини затяжного тіста використовували прилад для вимірювання ступеня деформації клейковини ІДК-2. Для визначення в'язкості емульсії використовувався капілярний віскозиметр. Визначення структурно-механічних характеристик тіста проводилося на приладі «Структурометр СТ-1» і фаринографі Брабендера. Форми зв'язку вологи в досліджуваних зразках тіста визначали методом термогравіметричного аналізу на приладі «Дериватограф Q-1500D» за зміною швидкості видалення вологи і величин теплових ефектів, що дозволило проаналізувати характер процесів, які відбувались при прогріванні досліджуваних зразків. Дослідження сорбційно-десорбційних властивостей затяжного печива проводили на сорбційно-вакуумній установці Мак-Бена.

Результати і обговорення. Під час досліджень використовувалась нетрадиційна для кондитерської галузі сировина, а саме зшитий модифікований крохмаль марки «Ні-Маize» та ізолят молочного білка. Зшитий модифікований крохмаль належить до групи стійких модифікованих крохмалів, які стійкі до розщеплення ферментами тонкого кишечника людини, а значить здатні без змін надходити до товстого кишечника, де виконують роль харчових волокон [6]. Споживання стійких крохмалів сприяє покращенню цілого ряду функцій організму людини, зокрема, зменшує рівень холестерину в крові, покращує функцію кишечника, зменшує ризики появи в ньому злоякісних пухлин тощо [7].

Стійкі крохмалі даної групи являють собою необроблені нежелатинізовані крохмалі в нативному вигляді, що знаходяться у вигляді гранул. Крохмаль в 
них щільно упакований, частково дегідратований, що обмежує його доступність для ензимів. Стійкі крохмалі характеризуються низькою калорійністю, яка знаходиться в межах 1,5-2,5 ккал/г, що дозволяє використовувати їх у розробці дієтичних продуктів. Слід також зазначити, що на відміну від традиційних джерел харчових волокон, зокрема продуктів переробки рослинної сировини (порошків, шротів і т.д.), стійкі крохмалі не створюють негативного впливу на якість готових виробів, а навпаки покращують структуру та зовнішній вигляд виробів, що робить їх ідеальним збагачувачем при виробництві борошняних кондитерських виробів.

Ізолят молочного білка служить джерелом тваринного білка 3 високим вмістом незамінних амінокислот [8]. Казеїн - складний білок молока, що відноситься до групи фосфопротеїдів. У молоці знаходиться у вигляді легкорозчинної кальцієвої солі. Середній вміст казеїну в молоці складає $3 \%$. Виділяють два види харчового казеїну: кислотний, що отримують коагуляцією білків знежиреного коров'ячого молока під дією молочної або соляної кислот та ферментний, який одержують коагуляцією білків знежиреного коров'ячого молока за допомогою молокозсідальних ферментних препаратів або пепсинів [9]. Готовий ізолят казеїну являє собою білий амфотерний порошок без ясно вираженого смаку і запаху, що дозволяе вносити його до рецептури печива без зміни його органолептичних властивостей та робить його дешевим та зручним білковим збагачувачем для функціональних продуктів [10].

Важливим етапом розробки нового виду затяжного печива було визначення оптимальної кількості нетрадиційних сировинних компонентів в рецептурі, при якому готове печиво матиме органолептичні показники не гірші, ніж у звичайного печива. При проведенні досліджень використовували три зразки печива: перший зразок - контроль, другий зразок - в тісто додавали зшитий крохмаль, третій зразок - додавали ізолят молочного білку. Оцінку якості печива проводилася за органолептичними показниками згідно ДСТУ 3781-14. Дослідні зразки печива, приготовані з нової сировини, відрізняються порівняно більшим об'ємом, рівномірною структурою в розломі, більшою щільністю і високими смаковими якостями. Оптимальна якість печива спостерігається при внесенні крохмалю в кількості $20 \%$, а білкового ізоляту $-8 \%$.

Окрім органолептичних показників суттєво змінюються також структурно-механічні і фізико-хімічні властивості емульсії для затяжного печива, які служать основним показником ii якості. Ці властивості характеризуються показниками стійкості емульсії до розшарування та іiі густиною. Для всіх трьох зразків рецептур печива було проведено визначення даних показників при температурі $40^{\circ}$ С. Густина емульсії для першого зразка $-1,01 \mathrm{r} / \mathrm{cm}^{3}$,

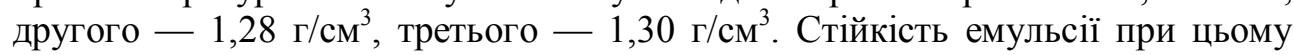
зростає відповідно в 2,5 і 2,7 раз, порівняно з контрольним зразком.

Проаналізувавши отримані дані, можна побачити, що при внесенні нової сировини спостерігається значне збільшення густини емульсії, що в свою чергу збільшує іiї стійкістю до розшарування. Зростання стійкості емульсії 
обумовлено активним зв'язуванням вологи зшитим крохмалем та молочним ізолятом, водопоглинальна здатність яких значно вища за водопоглинальну здатність борошна. Таке активне поглинання і зв'язування води, що вноситься в емульсію, зменшуючи кількість вільної вологи в емульсії, позитивно впливає на показник стійкості емульсії та підвищує іiі якість, однак значне зростання густини емульсії може викликати труднощі при транспортуванні емульсії в умовах виробництва, тому для забезпечення оптимальних умов тісто приготування рекомендується в емульсію вносити лише ізолят молочного білка, а зшитий крохмаль додавати разом з борошном в процесі замішування затяжного тіста.

Якість готового затяжного печива найбільше залежить від структурномеханічних властивостей тіста, з якого воно формується. Тісто для затяжного печива має мати пружно-еластичну структуру і не втрачати ії під час обробки, прокатки і формування тістових заготовок. Пружно-еластична структура тіста забезпечується, в першу чергу, клейковинним каркасом тіста, який утворюється за рахунок набухання білків клейковини. Для визначення впливу зшитого крохмалю та білкового ізоляту на властивості клейковинного каркасу затяжного тіста було проведено дослідження зразків тіста (табл. 1), замішаних згідно контрольної (№ 1) та відповідних робочих рецептур (№ 2, № 3), в які було внесено зшитий крохмаль та ізолят молочного білка.

\section{Таблиця 1. Показники якості клейковинного комплексу затяжного печива}

\begin{tabular}{|c|c|c|c|}
\hline \multirow{2}{*}{ Показники } & \multicolumn{3}{|c|}{ Номер зразка } \\
\cline { 2 - 4 } & $\begin{array}{c}\text { № } 1 \\
\text { контроль }\end{array}$ & $\begin{array}{c}\text { № 2 } \\
\text { 3 крохмалем }\end{array}$ & $\begin{array}{c}\text { № 3 } \\
\text { з крохмалем та } \\
\text { білковим ізолятом }\end{array}$ \\
\hline $\begin{array}{c}\text { Вміст клейковини, \% до маси } \\
\text { борошна }\end{array}$ & 26,4 & 22,3 & 18,6 \\
\hline Гідратаційна здатність, \% & 178,0 & 143,0 & 130,0 \\
\hline Розтяжність, см & 15 & 12 & 11 \\
\hline Пружність ІДК-2, од. пр. & 86,0 & 74,0 & 72,0 \\
\hline
\end{tabular}

Проаналізувавши отримані дані, можна стверджувати, що при внесенні в тісто зшитого крохмалю та ізоляту молочного білка, спостерігається укріплення клейковинного комплексу затяжного тіста - зменшується розтяжність та пружність клейковини. Внесення нової сировини також призводить до зменшення кількості сирої клейковини та значного падіння іії гідратаційної здатності (на 35 та 48\% відповідно), що свідчить про зменшення кількості вільної води в тісті i, очевидно, може бути зумовлено зв'язуванням вільної вологи клітковиною і білками, що вносяться до тіста 3 новою сировиною. Таке укріплення клейковинного комплексу відповідним чином також впливає на структурно-механічні показники затяжного тіста - підвищує його пружно-еластичні характеристики, знижує адгезивні властивості та зміцнює структуру тіста в цілому. Аналіз тіста, проведений на фаринографі (табл. 2) підтверджує висловлені припущення щодо впливу нової сировини на структуру тіста. 
Таблиия 2. Результати аналізу фаринограм

\begin{tabular}{|c|c|c|c|}
\hline \multirow{2}{*}{ Показники } & \multicolumn{3}{|c|}{ Номер зразка } \\
\cline { 2 - 4 } & $\begin{array}{c}\text { № } 1 \\
\text { контроль }\end{array}$ & $\begin{array}{c}\text { № 2 } \\
\text { з крохмалем }\end{array}$ & $\begin{array}{c}\text { № 3 } \\
\text { 3 крохмалем та } \\
\text { білковим ізолятом }\end{array}$ \\
\hline Водопоглинальна здатність & 58,6 & 59,4 & 61,0 \\
\hline Час утворення тіста, хв & 1,5 & 1,5 & 4,0 \\
\hline Стабільність, хв & 0,0 & 0,0 & 0,0 \\
\hline Розрідження, од. пр. & 120 & 125 & 135 \\
\hline Змішувальна цінність & 37 & 28 & 60 \\
\hline Розтяжність, од. пр. & 120 & 110 & 130 \\
\hline
\end{tabular}

Для визначення стану вологи в тістових масах застосований метод термогравіметрії. Дослідження проводили за допомогою приладу «Дериватограф Q-1500D» в діапазоні температур $20-200^{\circ}$ C. Досліджували зразки тіста 3 вологістю $27,5 \%$. Аналіз дериватограм було проведено відповідно до загальноприйнятої методики, результати представлені в табл. 3.

\section{Таблиия 3. Результати дериватографічного аналізу}

\begin{tabular}{|c|c|c|c|}
\hline \multirow{2}{*}{ Показник } & \multicolumn{3}{|c|}{ Номер зразка } \\
\cline { 2 - 4 } & $\begin{array}{c}\text { № 1 } \\
\text { контроль }\end{array}$ & $\begin{array}{c}\text { № 2 } \\
\text { з крохмалем }\end{array}$ & $\begin{array}{c}\text { № 3 } \\
\text { 3 крохмалем та } \\
\text { білковим ізолятом }\end{array}$ \\
\hline Загальна волога, \% & 27,0 & 27,0 & 27,0 \\
\hline Вільна волога, \% & 60,0 & 43,0 & 44,5 \\
\hline Зв’язана волога, \% & 40,0 & 57,0 & 55,5 \\
\hline Енергія активації, \% & 5,22 & 9,23 & 9,12 \\
\hline
\end{tabular}

Аналізу дериватограм вказує на те, що додавання зшитого крохмалю та білкового ізоляту істотно впливає на співвідношення вільної та зв'язаної вологи в затяжному тісті. Тісто 3 додаванням обох компонентів містить 55,5\% зв'язаної вологи, в той час як зразок тіста, що приготований на воді (контроль) містить лише 40\% зв'язаної вологи. Таке значне зростання кількості зв'язаної вологи можна пояснити наявністю міцних форм зв'язку вологи в зразках, відмінних від контрольного, зокрема найсуттєвіше волога може утримуватися завдяки харчовим волокнам, які вносяться в тісто разом зі зшитим крохмалем і здатні міцно зв'язувати вільну вологу. Ізолят молочного білка здатен зв'язувати значну кількість вологи, однак його вплив слабший, ніж у крохмалю, на що вказує менша результуюча кількість зв'язаної вологи, порівняно зі зразком без молочного ізоляту. Крім того присутнє підвищення енергії активації в зразках, відмінних від контрольного, що також свідчить про появу більш міцних форм зв'язку вологи в тісті після внесення до його складу нових компонентів.

Збільшення кількості зв'язаної вологи в тісті впливатиме на тривалість термооброблення затяжного печива і вимагатиме корегування тривалості та температури випікання нового затяжного печива. Окрім того зменшення кількості вільної вологи сповільнює процеси черствіння затяжного печива i позитивно впливає на процес його зберігання. Однак тривалість і умови збе- 
рігання печива обумовлює не лише кількість зв'язаної вологи, а й інтенсивність сорбційно-десорбційних процесів, що неминуче протікають при зберіганні, тому було проведено дослідження згаданих сорбційно-десорбційних процесів на сорбційно-вакуумній установці Мак-Бена. Результати досліджень показали незначний вплив крохмалю та ізоляту молочного білка на активність сорбційних процесів у затяжному печиві, рівноважна вологість у зразку печива, що містив обидва найменування нової сировини збільшилась лише на $2 \%$. Слід зазначити, що для затяжного печива, яке при зберіганні здатне активно поглинати вологу, навіть незначна сорбційна здатність матиме негативний вплив на якість продукту і термін зберігання, тому рекомендується упаковувати готове печиво у герметичну упаковку.

Нове затяжне печиво має найбільш близьке до оптимального співвідношення білків, жирів і вуглеводів в порівнянні 3 печивом «Марія», яке було обране в якості контролю, що свідчить про успішність збагачення. Оскільки крохмаль та ізолят молочного білка не мають ясно виражених смакових властивостей, то органолептичні показники готового печива $є$ ідентичними печиву «Марія». Енергетична цінність затяжного печива з ізолятом молочного білка та зшитим крохмалем - 379 ккал/100 г. Глікемічний індекс даного печива складає 38 одиниць, що на 10 одиниць менше, ніж у печива «Марія» (50 од.) і не перевищує межу в 40 одиниць.

\section{Висновки}

Проведені дослідження з розроблення нового затяжного печива показали, що включення до рецептури печива зшитого модифікованого крохмалю $\mathrm{i}$ ізоляту молочного білка дозволяють створити затяжне печиво з підвищеною харчовою і біологічною цінністю, зниженою калорійністю, яке збагачене білками і клітковиною, забезпечує потребу людини у харчових волокнах на $20 \%$, а у білках - на $15 \%$ від добової потреби, що дозволяє присвоїти йому статус продукту дієтично-функціонального призначення. Внесення нової сировини не значно впливає на технологічні параметри виробництва затяжного печива, що дозволяє виготовляти його на існуючому обладнанні, а високі органолептичні характеристики та функціональна спрямованість дозволяють рекомендувати його до вживання всім верствам населення, без суттєвих обмежень.

\section{Література}

1. Харченко Н.В. Дієтологія : підручник / за ред. : Н.В. Харченко, Г.А. Анохіна. Київ : Меридіан, 2012. - 526 с.

2. Острик А.С. Использывание нетрадиционного сырья в кондитерской промышленности: Справочник / А.С. Острик, А.Н. Дорохович, Н.В. Мироненко. - Киев : Урожай, 1989. $-112 \mathrm{c}$.

3. Яременко О.М. Розробка цукрового, здобного, затяжного печива з низьким показником глікемічності / О.М. Яременко, А.М. Дорохович // Наукові праці Національного університету харчових технологій. — 2008. — № 25. - С. 84-86.

4. Дорохович А.М. Розроблення інноваційних технологій цукрового, здобного та затяжного печива низької калорійності / А.М. Дорохович, О.М. Яременко // Стратегічні напрямки розвитку підприємств харчових виробництв, ресторанного господарства $\mathrm{i}$ торгівлі: міжнар. наук.-практ. конф., 19 листопада2008 р. : тези доповідей. - Харків : ХДУХТ, 2008. - С. 56-57. 
5. Маршалкин Г.А. Производство кондитерских изделий : Учеб. / Г.А. Маршалкин. Москва : Колос, 1994. - 272 с.

6. Полумбрик М.О. Вуглеводи в харчових продуктах і здоров'я людини / М.О. Полумбрик. - Київ : Академперіодика, 2011. - 487 с.

7. Fuentes-Zagarova E., Riquelme-Navarrete M.J., Sanchez-Zapata E. Resistant starch as functional ingredient: a review // Food Res. Int. 2010. - V. 43, P. 931—942.

8. Махинько В.М. Високобілкові добавки в хлібопеченні / В.М. Махинько, Л.М. Черниш // Хранение и переработка зерна. — 2014. - № 6(183). - С. 57-60.

9. Іщенко I. Навряд чи знайдеться ефективніший збагачувач хліба, ніж молочний казеїн / Т. Іщенко, О. Шидловська, Ю. Ткачук, В. Доценко // Хлібопекарська і кондитерська промисловість України. — 2009. - № 10(59). — С. 4-8.

10. Капрельяни Л. В. Функціональні продукти / Л.В. Капрельянц, К.Г. Іоргачова. Одеса : Друк, 2003. - 312 с. 